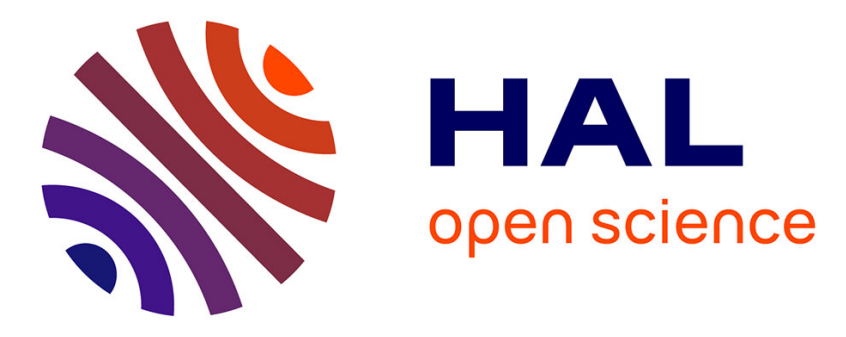

\title{
Study of Fractures Network in the Basement of Socotra Island-Yemen by Using Remote Sensing and GIS Techniques
}

Khaled Khanbari, Sylvie Leroy, Ahmad Adris, Sami Moheb-Al-Deen, Waheed Al-Sarari

\section{To cite this version:}

Khaled Khanbari, Sylvie Leroy, Ahmad Adris, Sami Moheb-Al-Deen, Waheed Al-Sarari. Study of Fractures Network in the Basement of Socotra Island-Yemen by Using Remote Sensing and GIS Techniques. Developing the African Continent through Space, Part 1, 32 (3), pp.207-218, 2020, 10.1007/978-3-030-32930-3_14. hal-03004330

\section{HAL Id: hal-03004330 \\ https://hal.science/hal-03004330}

Submitted on 20 Nov 2020

HAL is a multi-disciplinary open access archive for the deposit and dissemination of scientific research documents, whether they are published or not. The documents may come from teaching and research institutions in France or abroad, or from public or private research centers.
L'archive ouverte pluridisciplinaire HAL, est destinée au dépôt et à la diffusion de documents scientifiques de niveau recherche, publiés ou non, émanant des établissements d'enseignement et de recherche français ou étrangers, des laboratoires publics ou privés. 


\title{
Study of fractures network in the basement of Socotra Island - Yemen - by using remote sensing and GIS techniques
}

\author{
Khaled Khanbari ${ }^{1{ }^{\prime}}{ }^{\prime} *$, Sylvie Leroy ${ }^{2}$, Ahmad Adris ${ }^{3}$, Sami Moheb-Al-Deen ${ }^{3}$, Waheed \\ Al-Sarari ${ }^{3}$ \\ ${ }^{1}$ Department of Earth and Environmental Sciences, Sana'a University, Yemen \\ 2 ISTEP UPMC Paris, France \\ ${ }^{3}$ Yemen Remote Sensing and GIS Center, Yemen \\ * Corresponding author: Khaled Khanbari. E-mail address: kkhanbari@hotmail.com
}

\begin{abstract}
Fractured basement rocks have become an increasingly common target for hydrocarbon production in the Republic of Yemen, where the oil is in production from the deeply buried fractured basement. These basement reservoirs underlie a thick sequence of Mesozoic to Tertiary sediments and in order to study the characteristics of this buried basement, indirect methods must be used. The present work deals with the production of structural maps of basement of Socotra Island, and the extraction of lineaments from remote sensing data (satellite imageries and aerial photographs) as well as the analysis of these extracted lineaments by using GIS. The numerous fractures detected in the basement are characterized by consistent variations in trend, length and density when they affect the different lithological units out cropping in the study areas. The granitic basement is expected to have the best fractured reservoir potential. The dominant fracture trends in the basement of Socotra Island are NW-SE and NE-SW. The presence of this fracture system is thought to be due to major tectonic activity which formed new fractures and also reactivated older fractures.
\end{abstract}

\section{Introduction}

The occurrence of naturally fractured basement reservoirs has been known within the hydrocarbon industry for many years. Reservoirs in fractured basements, where the oil and gas in place may be within an extensive fracture network on variety of different scales. Fractured basement rocks have become an increasingly common target for hydrocarbon production in the Republic of Yemen, where the oil is in production from the deeply buried granitic/gneissic fractured basement. These basement reservoirs underlie a thick sequence of Mesozoic to Tertiary sediments and in order to study the characteristics of this buried basement, indirect methods must be used.

Remote Sensing and Geographic Information System (GIS) techniques help to identify the fractures that effect basement outcrops. Generally the fractures of basement outcrops reflect the characteristics of the buried basement. Therefore a greater understanding of fracture distribution within basement reservoirs using Remote Sensing and GIS techniques may prove to be the key tool for improved exploration and management of this hidden resource.

Socotra Island (Yemen) is located in the northwest Indian Ocean near the Gulf of Aden (Fig. 1). Socotra is about 120 by $40 \mathrm{~km}$ and covers an area of $3625 \mathrm{~km}^{2}$. It is composed of a basement complex of igneous and metamorphic rocks of Pre-Cambrian age overlain by sedimentary rocks, mainly limestone and sandstone. 
The main aim of this study is to explore the fracture network in the Pre-Cambrian rocks of Socotra Island from remote sensing data (satellite imageries and aerial photographs). Remote Sensing and GIS techniques were used to produce structural maps of the basement areas.

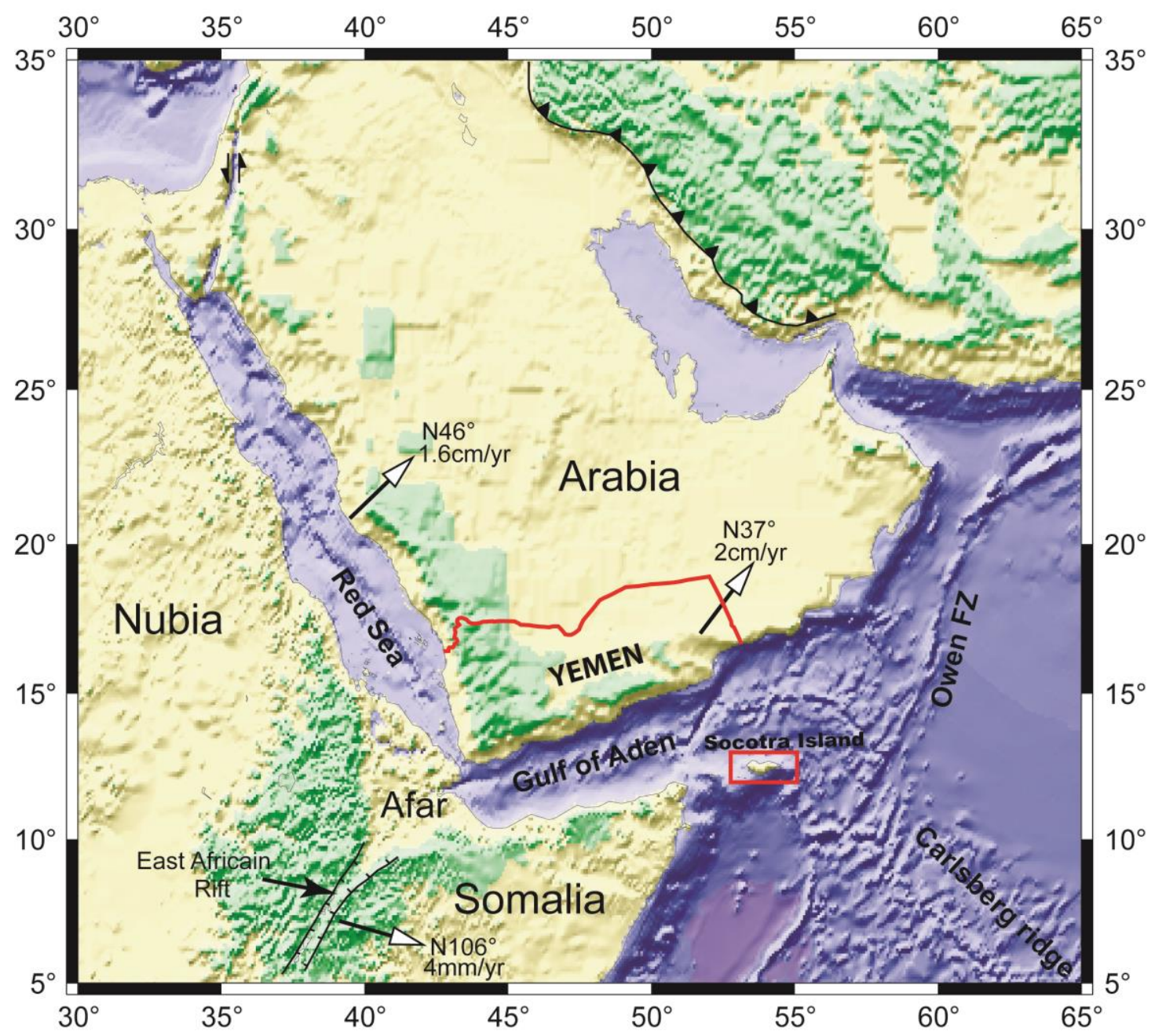

Figure 1: Topographic and bathymetric map of the Gulf of Aden and surrounding regions showing the location of Socotra Island and the direction and rate of motion of Arabia and Somalia with respect to Africa (Nubia and Somalia)

\section{Tectonic and Geological Setting}

The Socotra Island belongs to the southern continental margin of the Gulf of Aden (Fig. 1) which corresponds to a an active oblique rift system with young margins along the ArabiaSomalia plate boundary connects to the Indian Ocean to the east and to the Red Sea to the west. This rift separates the Somalia plate to the South and the Arabian plate to the North. Rifting history started around $35 \mathrm{Ma}$ and oceanic accretion is recorded since $17.6 \mathrm{Ma}$ to the east $^{12}$. The oceanic floor becomes younger in the westernmost part of the Gulf of Aden,

${ }^{1}$ Leroy, S., Gente, P., Fournier, M., d'Acremont, E., Bellahsen, N., Beslier, M.-O., Patriat, P., Maia, M., Blais, A., Perrot, J., Al-Kathiri, A., Merkouriev, S., Ruellan, P.-Y., Fleury, J.-M., Lepvrier, C., Huchon, P., 2004. From rifting to spreading in the eastern Gulf of Aden: a geophysical survey of a young oceanic basin from margin to margin. Terra Nova, 16, 185-192.

${ }_{2}$ Fournier M., Chamot-Rooke N., Petit C., Huchon P., Al-Kathiri A., Audin L., Beslier M.O., D'Acremont E., Fabbri O., Fleury JM., Khanbari K.,Lepvrier C., Leroy S., Maillot B. and Merkouriev S., 2010, Arabia-Somalia plate kinematics, evolution of the Aden -Owen-Carlsberg triple junction, and opening of the Gulf of Aden, J. Geophys. Res., V. 115, B04102. 
where the oldest magnetic anomaly corresponds to $3 \mathrm{Ma}^{3}$. This gulf results from an oblique rifting characterized by a direction of extension $\mathrm{N} 20^{\circ}$ and a rift oriented $\mathrm{N} 70^{\circ}{ }^{5}{ }^{6}$. The Socotra Island has occupied, prior to the Oligo-Miocene Gulf of Aden opening, a position between the proto-East Gondwana and the Arabian Nubian Shield ${ }^{7}$.

Socotra Island composed of a basement complex of igneous and metamorphic rocks of PreCambrian age overlain by sedimentary rocks, mainly limestone and sandstone (Fig. 2). It is covered by a carbonate-dominated Cretaceous and Tertiary succession unconformably overlying a Proterozoic and Paleozoic basement. Triassic and Jurassic deposits are locally preserved in a fault bounded area at the eastern end of the island.

Basement is exposed in three main areas of Socotra. The basement mainly includes PanAfrican granites, which make up the 1500m-high Haggier massif (Fig. 2). The oldest basement lithologies, metamorphosed to amphibolites facies, are metasediments, amphibolites and acid orthogneisses. These are intruded by gabbros, acid volcanics and a variety of acid plutons, including granodiorites, adamellites and peralkaline granites ${ }^{89}$.

On the island of Socotra, the southern passive margin of the Gulf of Aden displays along its strike two different types of asymmetric structures. Western Socotra is made up of a series of southward tilted blocks which are bounded by consistently northward dipping normal faults. Eastern Socotra consists of a broad asymmetric anticline with a steep northern limb and a gently dipping southern limb. A zone of NE-SW striking strike-slip and normal faults separates the two areas. The overall structure is interpreted as representing two rift segments separated by a transfer zone which is called Hadibo transfer zone ${ }^{10}$.

Three main outcrops of basement can be observed in Socotra Island (Fig. 2): Mont - Haggier area, Sherubrub area and Qalantssya area which is small and diffuse ${ }^{11}$. In this study, Mont Haggier and Sherubrub areas which represent the major outcrops of the basement, have been studied.

${ }^{3}$ Cochran, J.R., 1981. The Gulf of Aden: Structure and Evolution of a Young Ocean Basin and Continental Margin. J. Geophys. Res. 86 (B1), 263-287.

${ }^{4}$ Audin, L., 1999. Penetration de la dorsale d'Aden dans la depression Afar entre 20 et $4 \mathrm{Ma}$. PhD Thesis, Paris 7 University, France. 278 pp.

${ }^{5}$ Dauteuil, O., Huchon, P., Quemeneur, F., Souriot, T., 2001. Propagation of an oblique spreading center: the western Gulf of Aden. Tectonophysics 332, 423-442.

${ }^{6}$ D'Acremont, E., Leroy, S., Beslier, M.-O., Bellahsen, N., Fournier, M., Robin, C., Maia, M., and Gente, P., 2005. Structure and evolution of the eastern Gulf of Aden conjugate margins from seismic reflection data, Geophys. J. Int., 160, 869-890.

7 Denele Y., Leroy S., Pelleter E., Pik R., Talbot JY., Khanbari K., 2012, The Cryogenian arc formation and successive high-K calc-alkaline plutons of Socotra Island (Yemen), Arab J Geosci 5(5):903-924.

8 Beydoun Z.R., Bichan H.R., 1970, The geology of Socotra Island, Gulf of Aden. Quaterly J Soc Lond 25:413-446.

${ }^{9}$ Denele Y., Leroy S., Pelleter E., Pik R., Talbot JY., Khanbari K., 2012, The Cryogenian arc formation and successive high-K calc-alkaline plutons of Socotra Island (Yemen), Arab J Geosci 5(5):903-924.

${ }^{10}$ Fournier M., Huchon P., Khanbari K., Leroy S., 2007, Segmentation and along-strike asymmetry of the passive margin in Socotra, eastern Gulf of Aden: Are they controlled by detachment faults?, G3, Q03007.

${ }^{11}$ Denele Y., Leroy S., Pelleter E., Pik R., Talbot JY., Khanbari K., 2012, The Cryogenian arc formation and successive high-K calc-alkaline plutons of Socotra Island (Yemen), Arab J Geosci 5(5):903-924. 


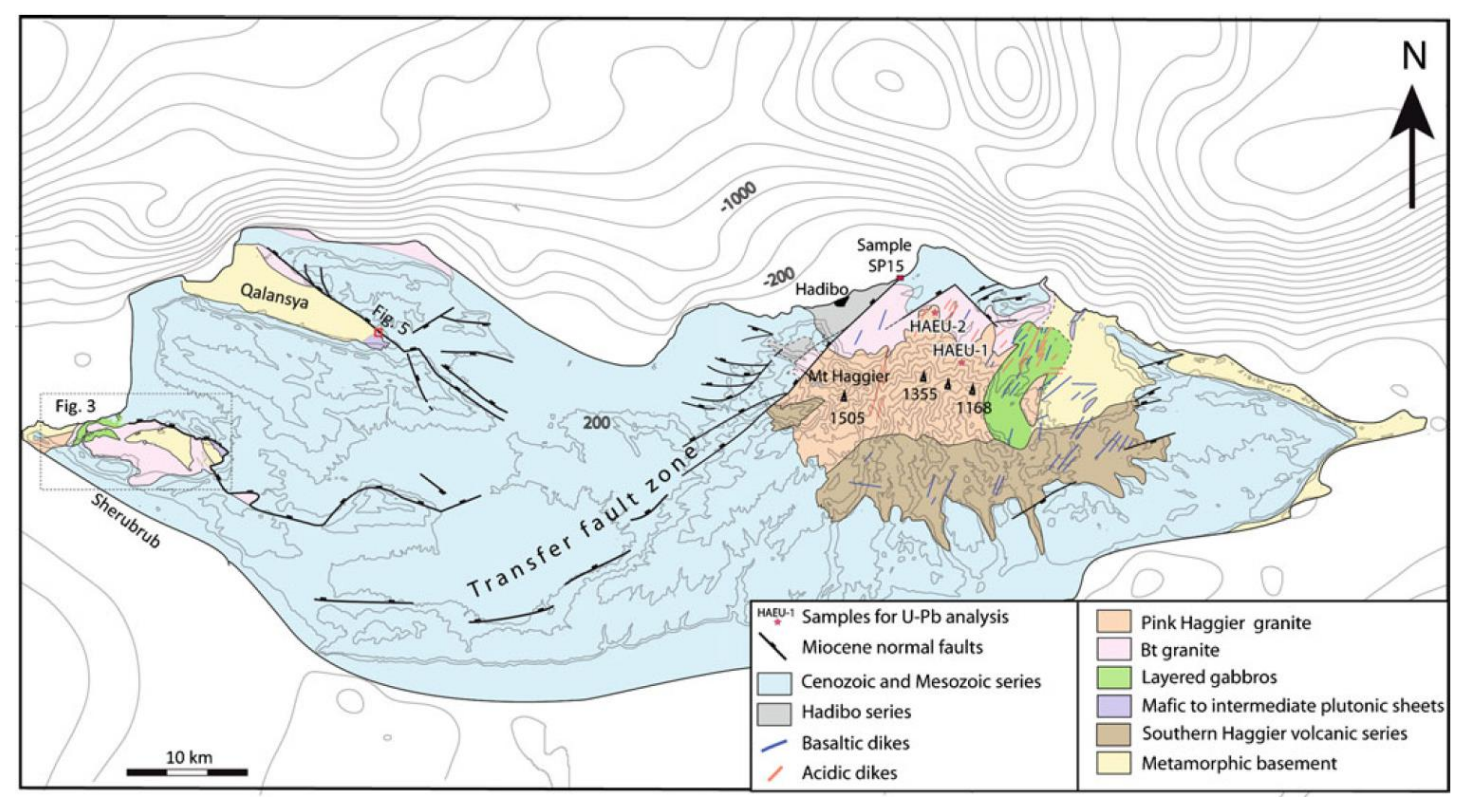

Figure 2: Geological and topographic map of Socotra Island showing the location of basement exposures in three main areas on Socotra

\section{Study of fractures network by remote sensing data}

Aerial photo interpretation technique was used for mapping the small fractures which effect the basement of Socotra Island, while Landsat-ETM image is used de identify the main structures such as major faults. Aerial photo mosaic with resolution of one meter and LandsatETM image have been interpreted by visual method in order to delineate the structures in the study areas (Mont-Haggier and Sherubrub area).

All structures derived from aerial photos and Landsat-ETM have been implemented in a GIS in order to obtain the related fracture maps, useful for the tectonic interpretation.The recognized structures have been analyzed by their trend.The numerous fractures detected are characterized by consistent variations in trend, length and density when they effect the different lithological units outcropping in the study areas.

\subsection{Mont-Haggier area (Eastern outcrop)}

Haggier mountains are located in eastern -central part Socotra Island (Fig.2). This basement massif occupies area of $662 \mathrm{Km}^{2}$ with the highest altitude in the Island $(1500 \mathrm{~m})$. The oldest basement rocks in Mont - Haggier area are the metamorphic basement which comprise Paragneisses and Micaschists, Orthogenesis, Amphibolite and Quartzites. The Metamorphic basement is overlain by Metavolcanic series which corresponds to an association of pyroclastic and effusive rocks ${ }^{13}$.

Structural map of Mont-Haggier area (Fig. 3) shows that the basement is effected by different type of geologic structures (fractures, faults, dykes) which have different trend, length and density. The rose diagram (Fig.4) shows that the dominant trends of fractures in Mont -

${ }^{12}$ Denele Y., Leroy S., Pelleter E., Pik R., Talbot JY., Khanbari K., 2012, The Cryogenian arc formation and successive high-K calc-alkaline plutons of Socotra Island (Yemen), Arab J Geosci 5(5):903-924.

${ }^{13}$ Denele Y., Leroy S., Pelleter E., Pik R., Talbot JY., Khanbari K., 2012, The Cryogenian arc formation and successive high-K calc-alkaline plutons of Socotra Island (Yemen), Arab J Geosci 5(5):903-924. 
Haggier area are NE-SW and NW- SE. Some other trends: N-S and E-W have been observed. The density map of fractures (Fig. 5) shows that the fracture density is high in the west and central parts of the study area which represent per-alkaline granites, while the other rock units are less affected by fractures.

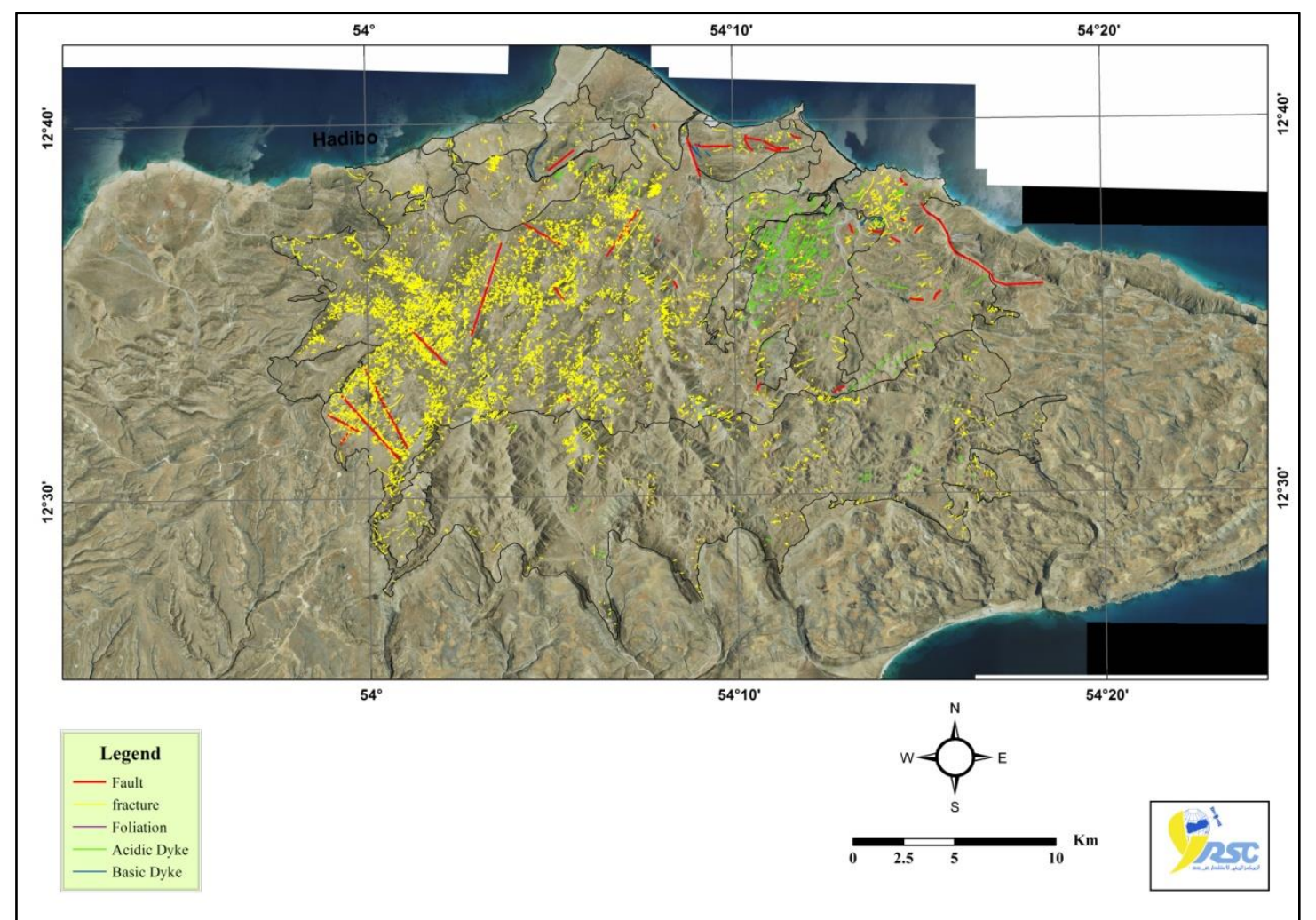

Figure 3: Structural map of Mont- Haggier basement (the background is aerial photo mosaic with resolution of one meter)

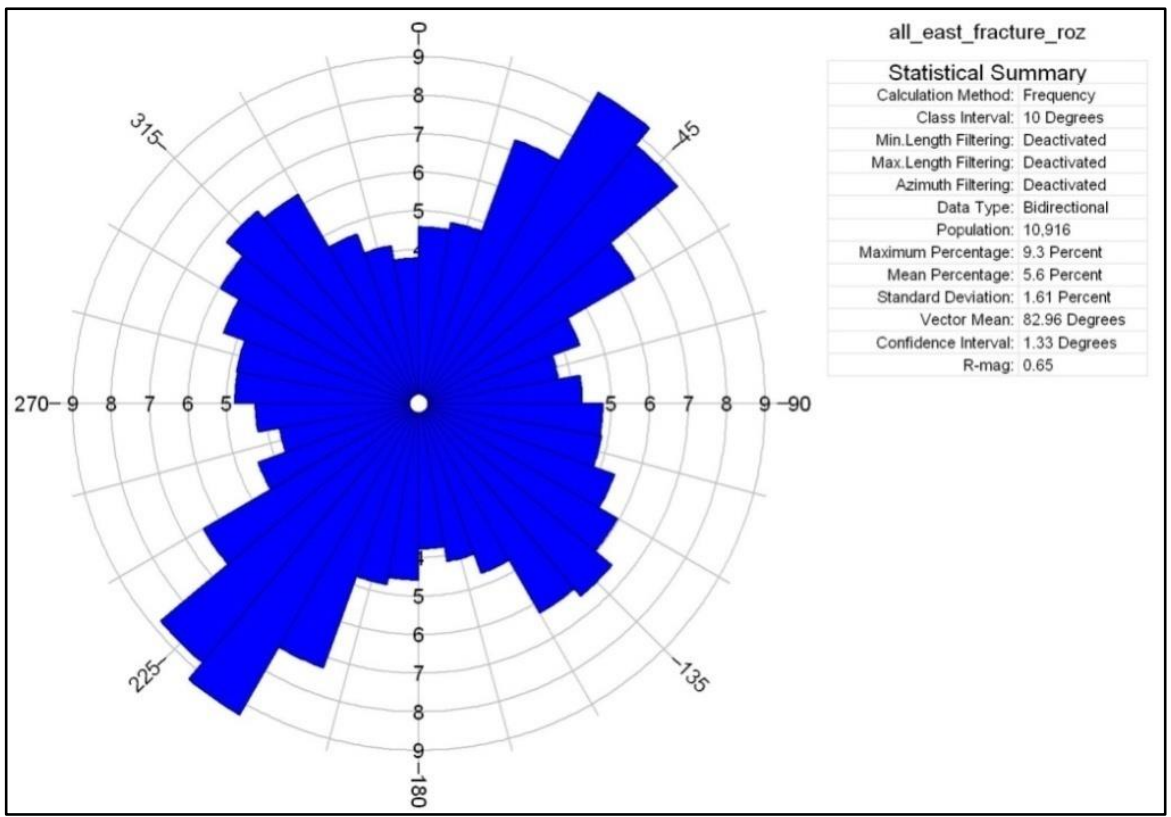

Figure 4: Rose diagram showing the trends of fractures in Mont -Haggier basement 


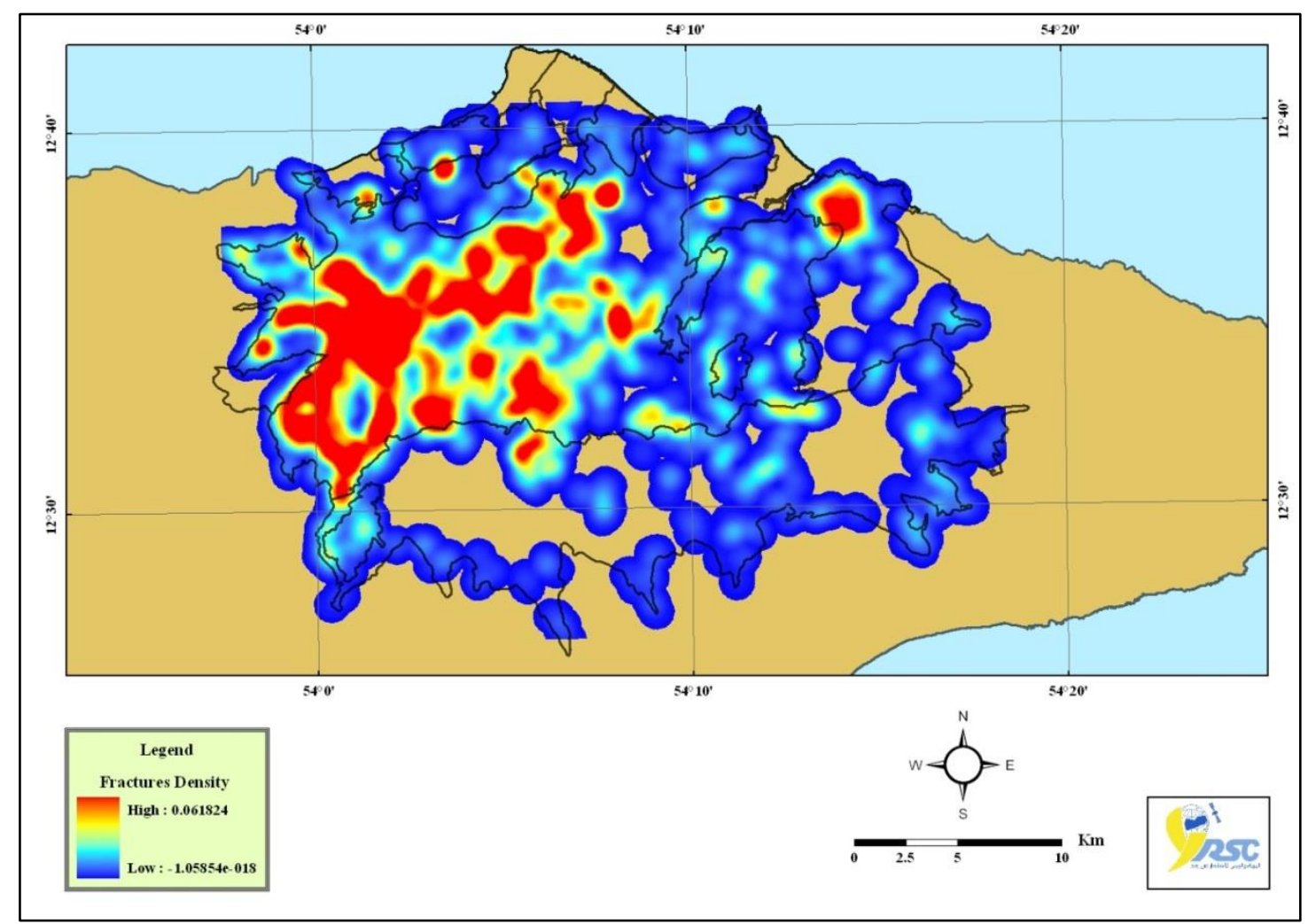

Figure 5: Density map of fractures in Mont -Haggier area

\subsection{Sherubrub area (western outcrop)}

Sherubrub basement is located in the western part of Socotra Island (Fig. 2). The basement occupies area about $53 \mathrm{Km}^{2}$. Sherubrub area is covered mainly by Granitic pluton which is constituted mainly by a pink Biotite-Hornblende granite. The pink granite and Gabbro are intended the metamorphic basement (Orthogenesis, Paragneisses, Quartzites). The volcanic dykes cut all petrographic formations in Sherubrub area. These dykes correspond to basaltic dykes with a microganular porphyric texture ${ }^{14}$.

Structural map of Sherubrub area (Fig. 6) shows that the basement is effected by different type of geologic structures (fracture, faults, dykes, floatation) which have different trend, length and density. The rose diagram (Fig. 7) shows that the dominant trends of fractures in Sherubrub area are NW-SE and NE- SW. All other trends such as N-S and E-W have been observed. The density map of fractures (Fig. 8) shows that the fracture density is high in the west and central parts of the study area which represent Paragneisses and Biotite-Hornblende granites, while the other rock units are less affected by fractures.

${ }^{14}$ Denele Y., Leroy S., Pelleter E., Pik R., Talbot JY., Khanbari K., 2012, The Cryogenian arc formation and successive high-K calc-alkaline plutons of Socotra Island (Yemen), Arab J Geosci 5(5):903-924. 


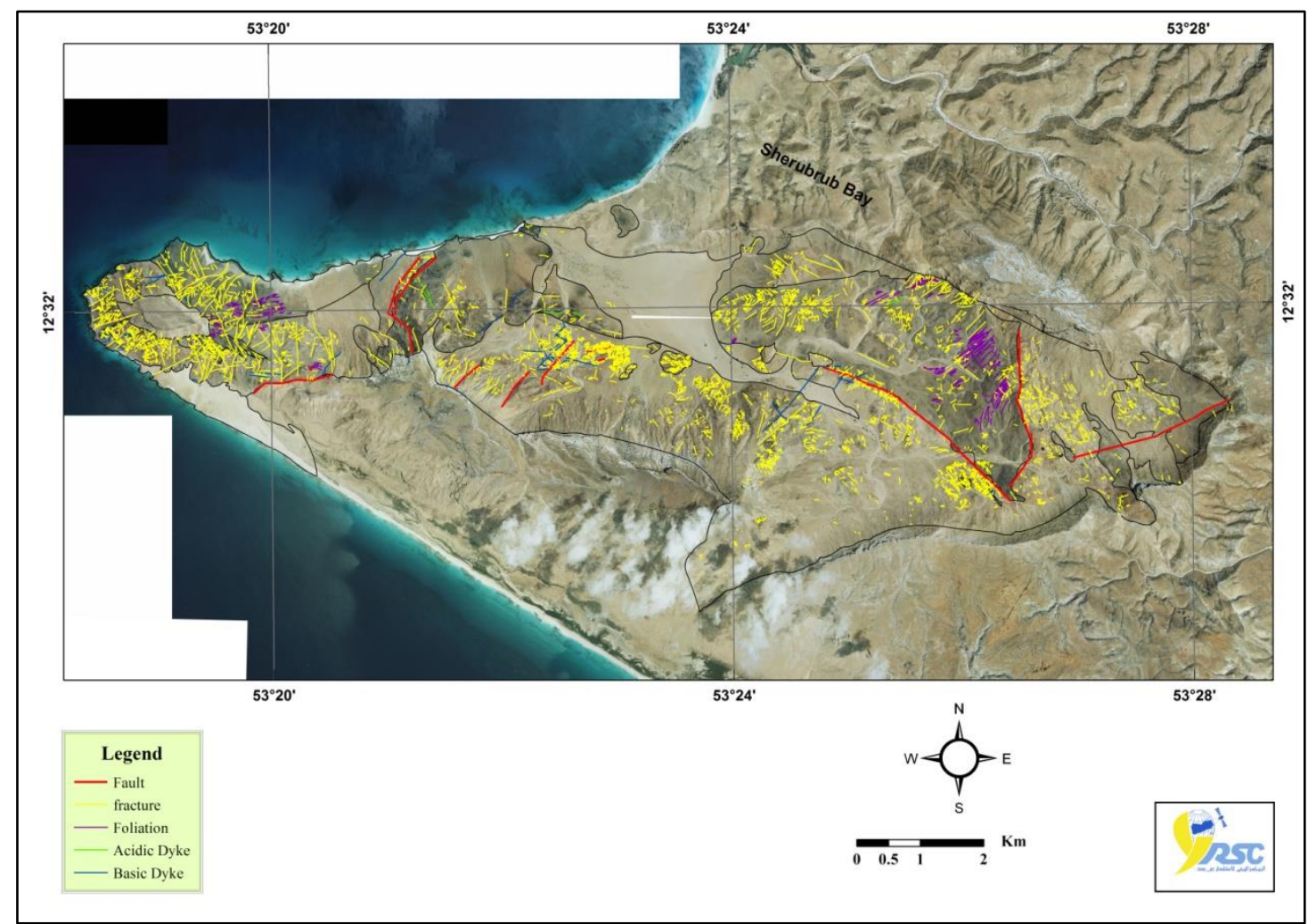

Figure 6: Structural map of Sherubrub basement (the background is aerial photo mosaic with resolution of one meter)

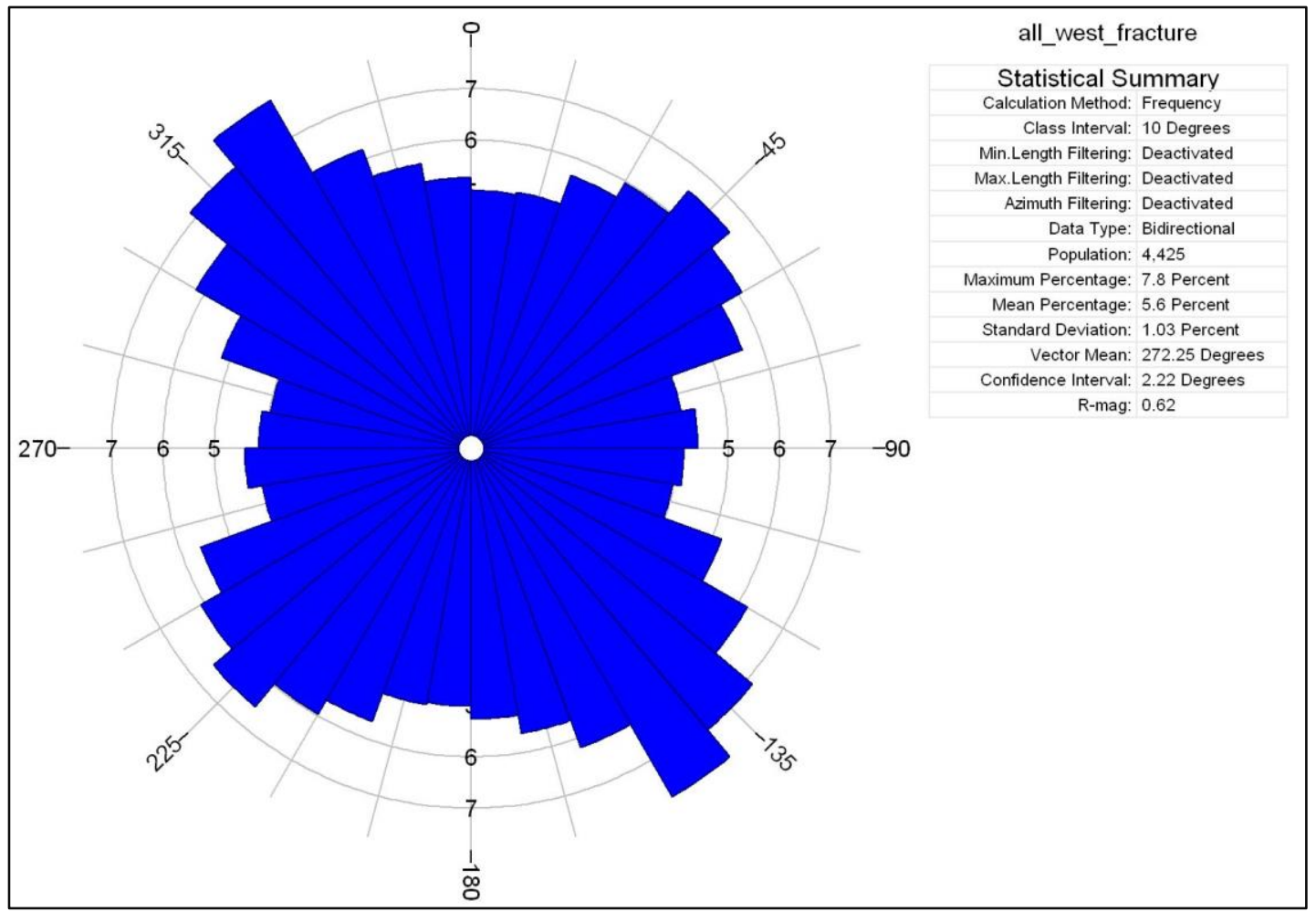

Figure 7: Rose diagram showing the trends of fractures in Sherubrub basement 


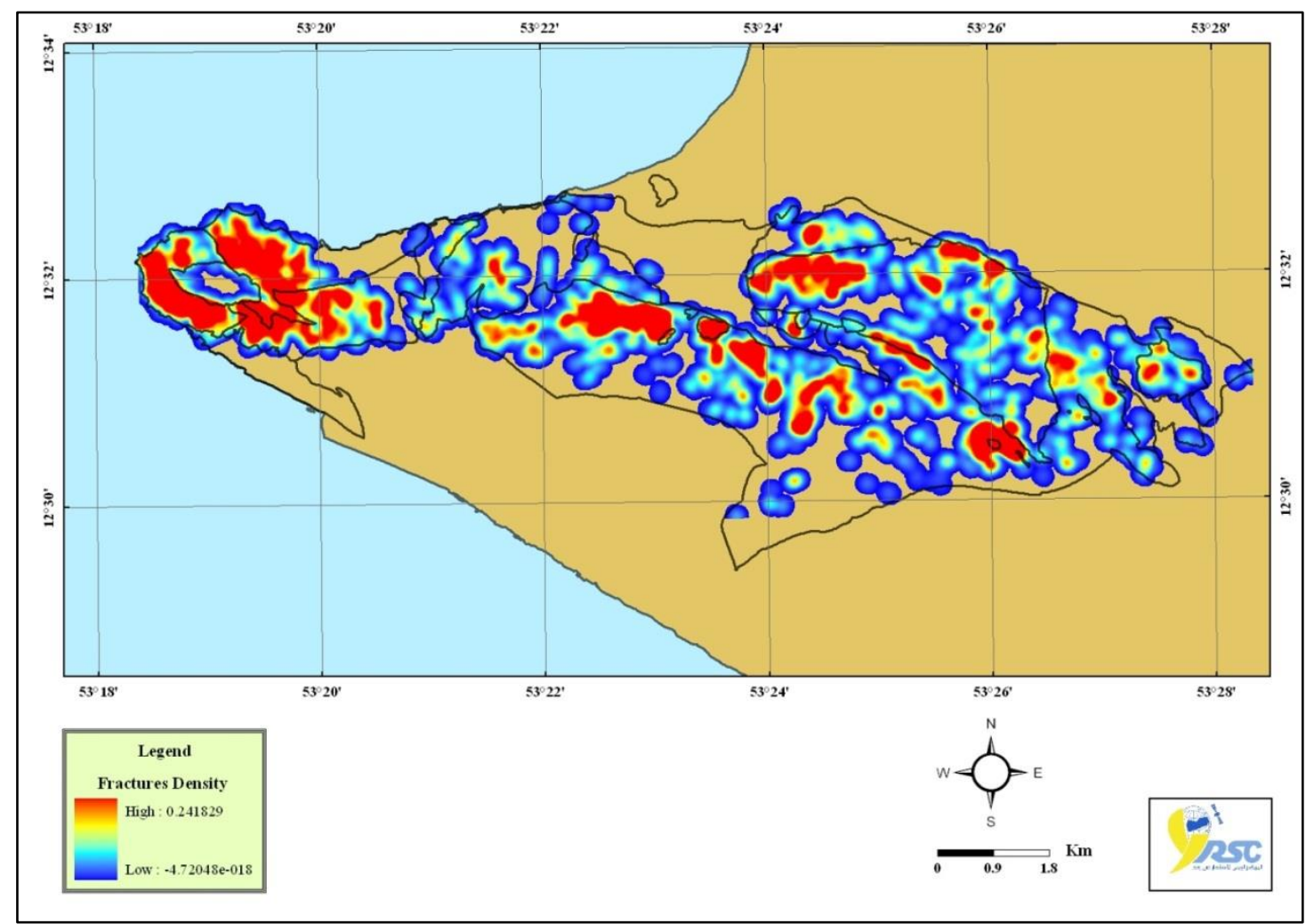

Figure 8: Density map of fractures in Sherubrub area

\section{Discussion and Conclusion}

Basement of Socotra is correlated with Proterozoic basement of Arabian plate (especially Yemen and Oman). The construction of the Gulf of Aden shows that the Socotra Island has occupied, prior to the Oligo-Miocene rifting, a position close to the Precambrian Mirbat and Al-Halaaniyat Islands outcrops in Oman ${ }^{15}{ }^{16}$. The Socotra Island has occupied, prior to the Oligo-Miocene Gulf of Aden opening, a position between the proto-East Gondwana and the Arabian Nubian Shield ${ }^{17}$.

The present work deals with the production of structural map of basement of Socotra Island, and the extraction of fractures from remote sensing data (satellite imageries and aerial photographs) as well as the analysis of these extracted fractures. The basement is exposed mainly in eastern Socotra (Mont-Haggier) and also in several western localities such as Sherubrub area. Basement of Socotra displays a great variety of metamorphic, plutonic and volcanic rocks.

${ }^{15}$ Denele Y., Leroy S., Pelleter E., Pik R., Talbot JY., Khanbari K., 2012, The Cryogenian arc formation and successive high-K calc-alkaline plutons of Socotra Island (Yemen), Arab J Geosci 5(5):903-924.

${ }^{16}$ Leroy, S., Razin, P., Autin, J., Bache, F., d'Acremont, E.,Watremez, L., Robinet, J., Baurion, C., Denele, Y., Bellahsen, N., Lucazeau, F., Rolandone, F., Rouzo, S., Kiel, J.S., Robin, C., Guillocheau, F., Tiberi, C., Basuyau, C., Beslier, M.O., Ebinger, C., Stuart, G., Ahmed, A., Khanbari, K., Al Ganad, I., de Clarens, P., Unternehr, P., Al Toubi, K., Al Lazki, A., 2012. From rifting to oceanic spreading in the Gulf of Aden: a synthesis. Arab. J. Geosci. 5 (5), 859-901.

${ }^{17}$ Denele Y., Leroy S., Pelleter E., Pik R., Talbot JY., Khanbari K., 2012, The Cryogenian arc formation and successive high-K calc-alkaline plutons of Socotra Island (Yemen), Arab J Geosci 5(5):903-924. 
The numerous fractures detected in the basement are characterized by consistent variations in trend, length and density when they affect the different lithological units out cropping in the study areas (Mont-Haggier and Sherubrub area). Fractures networks have been observed in all rock units. They exist over a wide range of scales from micro-fractures to largest faults. The fracture analysis shows two principal structural trends: NW-SE and NE-SW with less expressed trends around N-S and E-W. The average length of the fractures is about $25-100 \mathrm{~m}$.

Basement in Socotra Island is intensely fractured. The nature of fracture network varies with lithology. It appears that more homogeneous lithologies of magmatic origin have been better fracture properties than the layered formations of metamorphic origin. Therefore the granitic basement is expected to have the best fractured reservoir potential. Basement variations in Socotra Island are influenced by a number of factors including basement lithology and tectonic factor.

The dominant fracture trends in the basement of Socotra Island are NW-SE and NE-SW. The presence of this fracture system is thought to be due to major tectonic activity such as Tertiary opening the Gulf of Aden and Mesozoic break-up of Gondwana. These tectonic events formed new fractures and also reactivated older fractures.

Khaled Khanbari has a PhD in Geology, University of South Paris, France. He is Associated Professor at the Department of Earth and Environmental Sciences, Faculty of Sciences, Sana'a University. Dr. Khanbari is also chairman of Yemen Remote Sensing and GIS Center (YRSGISC). He carries out lectures on following courses: Remote sensing and GIS, Structural Geology and Tectonics, Surveying and Field Geology, Volcanic Activities in Yemen. During his work in (YRSGISC), Dr. Khanbari supervised and participated in many projects such as "Satellite Image Atlas of the Republic of Yemen" project and Unified Digital Map project of the Republic of Yemen. Dr. Khanbari has good relationship and experiences on research activities in Geoscience with the French PMCU University. He coordinated one Yemeni-French scientific project YOCMAL which aims to study the geology of Socotra Island and the evolution of the Gulf of Aden. Dr. Khanbari improved his qualification on Geology, GIS and Remote Sensing by attending many of local and regional workshops and conferences. He supervised many of bachelor final projects and master thesis in the fields of Geology GIS, Remote Sensing. He has published many of scientific articles in local and international scientific journals. kkhanbari@ hotmail.com

Sylvie Leroy has a PhD in Geodynamic, University of Pierre and Marie Curie, France. She is director at the Institute of Earth Sciences of Paris (ISTEP). Dr. Leroy is also mission manager of Marine Geoscience at National Institute for Earth Sciences and Astronomy (INSU). She is a head of the Lithosphere-Structure-Deformation team. Dr. Leroy is manger of many projects such as YOCMAL project which aims to study the geology of Socotra Island and the evolution of the Gulf of Aden. Dr. Leroy supervised many of master and PhD theses. She has published many of scientific articles in international scientific journals. Sylvie.leroy@umpc.fr, Sylvie.leroy@sorbonne-universite.fr

Ahmad Adris has a $\mathrm{PhD}$ in Technical Science. Yerevan State University, Armenia. He is a Researcher in RS, GIS \& WRM at the Department of Geology and Water Resources, General Organization of Remote Sensing (GORS), Syria. Dr. Adris is also Scientific Consultant and Founder of Smart Live Yemen Initiative. He worked as expert in RS \& GIS at Yemen Remote Sensing and GIS Center (YRSGISC) for 7 years (2010-2017), and at Hydroscope L.T.D. company, Armenia for more 10 years as GIS analyst - Interpreter of Satellite Images Geophysicist. During his work, Dr. Adris supervised and participated in many projects such as "Determine optimal sites for Dams for Sana'a basin using RS \& GIS techniques", "Study the karst phenomena (cavities) in the Ras-Alain district (in favor of the Directorate of Water Resources in Al-Hasakah governorate, Ministry of Irrigation, Syria)". Dr. Adris improved his 
qualification on RS, GIS and Water Resources Management by attending many of local and regional workshops and conferences. He supervised many of bachelor final projects thesis in the fields of Geology GIS, Remote Sensing. He has published many of scientific articles in local and international scientific journals. He Joined: Syrian Geological Society in 1994, Planetearth Forum" Pace for Sustainable Development" in 2014. geophysicall@ yahoo.com

Sami Moheb Al-Deen has Postgraduate Degree in Geology (Petroleum \& Stratigraphy unit) from Faculty of Science, Sana'a University, Yemen. He was Teaching-Assistant in Geology Sana'a University for one year. Eng. Mohab Al-Deen is the Manager of Remote Sensing Department in Yemen Remote Sensing \& GIS Center (YRSGISC). He is a Specialist in Remote Sensing and GIS with +13 years' experience in YRSGISC. Eng. Mohab Al-Deen held a training course on Remote Sensing and GIS at different governmental authorities such as General Telecomm Institute (GTI), Public Electricity Corp \& -General Authority for the Conservation of Cities and Historical Monuments (GAPHCMY). He is GIS Consultant in Social Fund for Development (SFD) and Emergency Response Unit in the Ministry of Water and Environment. samoh2010@gmail.com

Waheed Al-Sarari has Postgraduate Degree in Geology from Faculty of Science, Taiz University, Yemen. He is the Manager of Scientific Researches and Environmental Studies Department in Yemen Remote Sensing \& GIS Center (YRSGISC). He is a Specialist in Remote Sensing and GIS with +13 years' experience in YRSGISC. Eng. Al-Sarari improved his qualification on GIS and Remote Sensing by attending many of training courses and workshops. During his work in YRSGISC, he participated in many projects such as "Satellite Image Atlas of the Republic of Yemen" project and Unified Digital Map project of the Republic of Yemen.walsarari@gmail.com 